\title{
311 <需要変動を考慮したエ場設備レイアウト設計に関する一考察〉
}

$<$ A study on facility layout planning considering demand fluctuation >

$$
\text { <水本一生 } \cdot \text { 大阪大学> }
$$

$<$ Issei Mizumoto, Osaka University>

<森永英二・大阪大学 $>$

$<$ Eiji Morinaga, Osaka University >

$$
\text { <若松栄史・大阪大学> }
$$

$<$ Hidefumi Wakamatsu, Osaka University >
<荒井栄司・大阪大学>

$<$ Eiji Arai, Osaka University $>$

The facility layout problem has been studied by a lot of researchers. Most of the researches have formulated the layout planning problem as a minimization problem of the transportation distance and the transportation cost. In the formulations, production demand is assumed to be constant. Therefore, re-planning and change of facility layout are required when the production demand has changed. This is unacceptable when such demand change occur frequently. This research considers planning of a robust facility layout against the demand change, and reports the result of formulation of the layout planning as an optimization of the sensitivity for the demand change.

Key Words: facility layout planning, demand fluctuation

\section{1. はじめに}

設備レイアウト設計問題は、生産システムを設計する上で 基本的な問題の一つであり、古くから多くのモデル、レイア ウト表現、解法の研究がなされてきた。まず、モデルについ てては、通路、I/O ポイント、柱などの工場内部の構造を考慮 したものや、多層階工場におけるエレベータの面積、位置を 考慮したものなど実際の工場の再現性を高めるための研究 が多くなされてきた。それらの研究では概ね、各職場間を流 れる物流量が与えられたもとで、目的関数として物流量と移 動距離の積の総和である搬送距離や搬送距離と単位距離当 たりの搬送コストの積の総和である搬送コストを最小化す る問題に帰着させるアプローチが採られている(1) (4)。

昨今、消費者ニーズの多様化等により、少品種多量生産か ら変種変量生産に生産形態が移行している。そのような形態 では、需要量を的確に予測して生産することが強く望まれる が、実際には困難であり、需要の変動に対して柔軟に対応す ることが必要不可欠となる。しかし、変動に対して頻繁に設 備配置を変更することは一般に相当なコストが発生するた め好ましくない。したがって、変動の発生の可能性を考慮し た設備レイアウト設計を行う必要があるが、搬送距離や搬送 コストを評価指標として最適化問題に帰着させる従来のア プローチでは対応できない。

需要変動を考慮する一つのアプローチとして、ダイナミッ ク設備レイアウト問題(Dynamic Facility Layout Problem)があ る。このアプローチは需要変動によって生じる設備の増設・ 削減、職場の拡大・縮小に対応するために、目的関数を建屋 建築コストと配置変更コスト、搬送コストの総和を最小化す るアプローチが採られている(5)。

もう一つのアプローチとして、変動の影響を受けにくい設 備レイアウトを追求するものが考えられる。本研究では、こ の立場に立ち、ジョブショップ型の生産システムにおいて目 的関数を搬送距離や搬送コストではなく、搬送距離の感度関 数を用いることで設備レイアウトを変更せず、生産量の変動 に対してできるだけロバストな設備レイアウト設計手法に ついて考察を行ったので報告する。

\section{2. 定式化}

本研究では生産量の変動を考慮するための一つの方策と
して、従来用いられてきた搬送距離ではなく、変動に対する 搬送距離の感度関数を評価指標とすることを考える。 $f$ を製 品の生産数、 $F$ を総搬送距離とすると、感度関数 $S_{f}^{F}$ は $f$ の変 化率を $F$ の変化率で割った(1)式のように定義される。

$$
S_{f}^{F}=\frac{\frac{\partial f}{f}}{\frac{\partial F}{F}}=\frac{f}{F} \cdot \frac{\partial F}{\partial f}
$$

ここでは、搬送距離を物流量と設備間距離の積として定義 し、各製品の搬送距離の感度関数の二乗和を評価指標とする ことで、(2)式のような目的関数を設定する。なお、ここでの 設備間距離は、(3)式のように設備の重心間のマンハッタン距 離とする。設備の向きを決定するための式は(4) (6)式で記 述される。各設備は施設の内部に配置される必要があり、ま た設備同士が重ならないようにする必要がある。これらの制 約条件はそれぞれ(7) (9)式で記述できる。

$$
\begin{aligned}
& \min : \sum_{k}\left(S_{f_{k}}^{F}\right)^{2}=\sum_{k}\left(\frac{\sum_{i} \sum_{j} f_{i j k} d_{i j}}{\sum_{k} \sum_{i} \sum_{j} f_{i j k} d_{i j}}\right)^{2} \\
& d_{i j}=\left|x_{i}-x_{j}\right|+\left|y_{i}-y_{j}\right| \\
& w_{i}=p_{i} l_{i}^{s}+\left(1-p_{i}\right) l_{i}^{s} \\
& l_{i}=p_{i} l_{i}^{l}+\left(1-p_{i}\right) l_{i}^{s} \\
& p_{i} \in\{0,1\}
\end{aligned}
$$

制約条件

$$
\begin{aligned}
& x_{j}+w_{j} / 2 \geq W, y_{i}+l_{i} / 2 \geq L \\
& x_{j}-w_{j} / 2 \geq 0, y_{i}-l_{i} / 2 \geq 0 \\
& \max \left(\left|x_{i}-x_{j}\right|-\left(w_{i}+w_{j}\right) / 2,\left|y_{i}-y_{j}\right|-\left(l_{i}+l_{j}\right) / 2\right) \geq 0
\end{aligned}
$$

変数の説明を次にあげる。 $n:$ 職場数

$f_{i j k}:$ 製品 $k$ の職場 $i, j$ 間の物流量 
$d_{i j}$ : 設備 $i, j$ 間距離

$x_{i}, y_{i}$ : 設備 $i$ 重心の $x$ 座標、 $y$ 座標

$p_{i}$ : 設備 $i$ の向きを表す 0-1 変数

$l_{i}^{s}, l_{i}^{l}$ :設備 $i$ の長辺、短辺の長さ

$w_{i}, l_{i}$ : 設備 $i$ の $x, y$ 軸方向の長さ

$W, L:$ 施設の $x 、 y$ 軸方向の長さ

\section{3. ケーススタディ}

3-1 入力情報 製品の予測生産量、設備間の物流量、設備の 長辺、短辺の長さ、施設の大きさを入力情報とする。

3-2 モデル モデルとしては、ジョブショップ型の生産シス テムにおいて、設備台数 6 台、製品数 3 とした。また、各設 備は矩形であり、大きさは既知として、表 1 に示す。製品 1 ～3 の生産数はそれぞれ 10、20、30 とし、使用する設備は、 それぞれ $2 \rightarrow 4 \rightarrow 5 、 3 \rightarrow 5 \rightarrow 6 、 1 \rightarrow 4 \rightarrow 3$ とする。

表 1. 設備の大きさ

\begin{tabular}{|c|c|c|c|c|c|c|}
\hline 設備 & 1 & 2 & 3 & 4 & 5 & 6 \\
\hline $\mathrm{x}$ & 7 & 5 & 10 & 8 & 8 & 6 \\
\hline $\mathrm{y}$ & 4 & 4 & 6 & 7 & 7 & 6 \\
\hline
\end{tabular}

このモデルに対して、目的関数を搬送距離、感度関数のそ れぞれを最小化した結果を次に示す。

3-3 計算結果、考察 搬送距離を最小化した時の設備配置の 結果は表 2、図 1 のようになった。そして、その搬送距離は 805、感度関数は 0.354 であった。なお、表 2、3、図 $1 、 2$ に おける座標は設備の重心の位置を表している。

表 2. 搬送距離最小化の結果

\begin{tabular}{|l|l|l|l|l|l|l|}
\hline 設備 & 1 & 2 & 3 & 4 & 5 & 6 \\
\hline $\mathrm{x}$ & 7.5 & 2 & 14 & 7.5 & 20.5 & 15.5 \\
\hline $\mathrm{y}$ & 3.5 & 9 & 9 & 9 & 9 & 15.5 \\
\hline
\end{tabular}

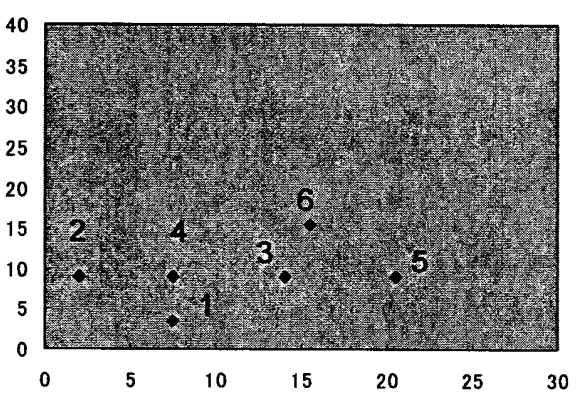

図 1. 搬送距離最小化の結果

次に感度関数を最小化した時の設備配置の結果は表 3、図 2 のようになった。そして、その搬送距離は 2967.6、感度関数 は 0.333 であった。

表 3. 感度関数最小化の結果

\begin{tabular}{|l|l|l|l|l|l|l|}
\hline 設備 & 1 & 2 & 3 & 4 & 5 & 6 \\
\hline $\mathrm{x}$ & 5.4 & 27.9 & 8.4 & 4.0 & 23.7 & 3.5 \\
\hline $\mathrm{y}$ & 29.3 & 6.8 & 19.5 & 37.9 & 13.7 & 5.5 \\
\hline
\end{tabular}

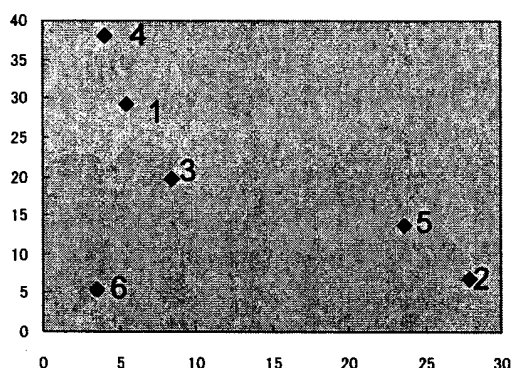

図 2. 感度関数の最小化の結果

目的関数を搬送距離とした場合と変動に対する感度を搬 送距離の感度関数とした場合とでは、最適解が異なる結果と なった。この例では、搬送距離そのものを評価対象としてい る前者の方が当然ながら搬送距離、そして配置面積の点で優 れた結果となっている。しかし、最適解が異なるという事実 は、従来の指標が生産量の変動に対するロバスト性という点 では必ずしも十分ではなく、別の指標を考慮することが必要 であること、感度が一つの指標となり得ることを示唆してい ると解积できる。

なお、最適化手法として、搬送距離の最小化では、ILOG 社の CPLEXによる組み合わせ最適化手法、感度関数の最小 化では、iSIGHT の遺伝的アルゴリズムによる計算を行った。

\section{4. おわりに}

本稿では、需要量の変動を考慮して、そのような変動の影 響を受けにくい設備レイアウトを設計するアプローチにつ いて考察を行った。新たな評価指標の一つとして、変動に対 する感度を組み込んだ評価関数を設定し、ケーススタディに よる考察を行った。その結果、変動に対する感度を考慮に入 れることの妥当性を示すことができた。今後、感度と従来指 標の統合化や変動の生起確率の考慮等について検討を行う 必要がある。

謝辞

ケーススタディの最適化計算において協力いただいた、大 阪大学佐藤了平教授、岩田剛治准教授に感謝致します。

参考文献

(1) Russell D.Meller and Kai-Yin Gau、"The Facility Layout Problem: Recent and Emerging Trends and Perspectibes"、 Journal of Manufacturing Systems 、 Vol.15 、 No.5 、 pp.351-366(1996)

（2）伊藤隆史、伊呂原隆、“詳細な I/O 位置を考慮した多層 階レイアウト技法の提案”、日本経営工学会論文誌、 Vol.57、No.5、pp.376-403(2006)

(3) 藤川裕晃、白井裕、伊呂原隆、“柱の位置と物流コスト を同時に考慮した職場配置方法の研究”日本設備管理学 会誌、Vol.16、No.2、pp.1-7(2004)

（4）鈴木博人、铇田真也、反町貴子、吉本一穗、“運搬通路 を考慮した施設レイアウト技法の開発”、日本機械学会 論文集(C 編)、Vol.73、No.728、pp.303-308(2007)

(5) Panitarn PEERAPATTANA、平林直樹、長沢啓行、“ダイ ナミック設備レイアウトにおける多段階近似解法”、シ ステム制御情報学会論文誌、Vol.17、No.4、 pp.178-186(2004) 